\title{
African Botanical Heritage for New Crop Development
}

\author{
Patrick Van Damme, Céline Termote \\ Laboratory of Tropical and Subtropical Agriculture and Ethnobotany, \\ Ghent University
}

\begin{abstract}
The African continent is rather poor in plant biodiversity when compared to other continents on and around the equator. Nevertheless, lots of useful plant species have been domesticated from Sub-Sahara Africa material. Ethnobotanical research offers the possibility to collect information on the use and utility of wild plant species from traditional peoples often living in or close to a challenging natural environment. This type of information then allows us to find new candidates for domestication and subsequent crop development for income generation and increased food security. The case of Gnetum africanum illustrates the practical implications of developing a lesserknown species, and highlights the institutional problems that go together with niche crop development. The latter are subsequently presented and discussed in extenso, and solutions proposed in a second part of this review text.
\end{abstract}

Key words: Ethnobotany, Domestication, Non-timber Forest Product, Value Chain, Marketing

\section{Introduction}

Africa is a big continent that harbours a wide agro-ecological variation, based on a variety of climates and soils. The latter interact to yield a number of biomes that cover a vegetation range comprising dry woodland and shrubland in the north, deserts (Sahara and Namib desert being the most prominent on and near the Tropics of Cancer and Capricorn), evergreen broadleaf forest, tropical deciduous forest, tropical scrub forest, tropical savannah and woodland, semi-desert and arid grasslands and mountainous vegetations (sensu White, 1983).

Annual rainfall figures range from $25 \mathrm{~mm}$ to $8000 \mathrm{~mm}$. However, the natural environments they generate are mostly influenced and changed by human intervention. Sedentary farmers, transhumant and nomadic cattle growers use and shape the natural landscape in such a way that the original vegetation is altered into a man-made environment, with a specific biodiversity. Cropping can either be intensive or extensive, using traditional - some would say primitive - implements or else rather modern inputs in an effort to lower production risks and increase yields.

In terms of farming the continent exhibits the whole range of agricultural production systems starting with (again) primitive hunter-gatherer systems (like the ones 
encountered with central African pygmies or southern African Kung San or Topnaar, formerly known as Bushmen and Hottentots, respectively), and developing into seminomadic and subsequently fallow systems, ley farming, permanent upland farming and when resources allow, irrigation farming and plantation farming. In limiting (arid) environments animal husbandry systems prevail and cattle, goats and sheep are raised for auto-subsistence and marketing (Ruthenberg, 1976).

The different vegetation types do not make up the widest variety of plant biodiversity in the world. In fact, Latin America hosts some of the most biodiverse 'hotspots' of the world, while Asia also has some very rich sites. Wherever there is rich plant diversity, there is a basis for subsequent plant domestication into crops. Thus, both Latin America and Asia have been the cradle of a number of important crops. By comparison, Africa is rather poor. Still, and following Vavilov's Centres of Origin theory, Africa is the centre of origin of a number of well-known crops that have a worldwide importance. Moreover, it hosts a number of plant species with local and/or regional importance that just 'wait' to be developed into real crops.

The present review highlights a number of crops of African origin(s), but also draws the reader's attention to a number of useful species with domestication potential which are currently under consideration for domestication and/or are currently being developed. Specific attention will be drawn to the methodology allows the 'finding' of new candidates for crop and niche product development, with a specific emphasis on market chain analysis and promotion, and the development aspects of the latter process. Furthermore, the case of Gnetum africanum, a wild leafy vegetable of Central Africa, will be presented in more detail.

\section{African Crops}

\subsection{The 'big four'}

Coffea arabica and $C$. canephora (better known as robusta coffee) together with the lesser known and used $C$. liberica, are three coffee species that have been present in international markets for several centuries. C. arabica was first domesticated in the Horn of Africa, then moved into the Arab peninsula before it began its tour du monde. Robusta is a species that was first domesticated from the humid tropical lowland forests of central Africa. Both co-exist and have specific markets and customers, robusta being the source of soluble coffee as it has a strong, somewhat bitter flavour that stands up well to processing.

Amongst the different cotton species (Gossypium spp.) that are grown worldwide, at least one originated from Africa. In fact, cotton is mentioned in the New Testament (more specifically referring to Egypt). However, archaeological findings in Thailand and Machu Pichu point to a disjunct origin for the genus that indeed contains several species that each developed into commercial crops.

At the commercial level, Elaeis guineensis or oil palm is a real success. It originated in the Guinea Gulf area and is now 'big money' in South East Asia, with Malaysia and Indonesia being the biggest producers, followed by Vietnam. Oil palms offer a healthy vegeta- 
ble oil whose properties have been altered for greater nutritious value and better health properties. It was previously the second-most widely produced edible oil, after soybean, 28 million metric tons were produced worldwide in 2004. It may now well have surpassed soybean oil as the most widely produced vegetable oil in the world. Recent interest in biofuels based on energy-rich chemical compounds from oil crops has increased investment efforts to promote its cultivation in new areas (many of which are situated in fragile humid tropical environments). This is explained by the crop's unparalleled productivity. Simply put, oil palm is the most productive oil seed in the world. A single hectare of oil palm may yield 5,000 kilograms of crude oil, or nearly 6,00o litres of crude according to data from JourneytoForever. In comparison, soybeans and corn - crops often heralded as top biofuel sources - generate only 446 and 172 litres per hectare, respectively (various FAO statistical yearbooks; www.fao.org). However, the problems that organisations such as Greenpeace have linked to palm cultivation on newly-cleared plantations have encouraged research into alternative vegetable fuel oil sources with less potential for environmental damage, such as jatropha (Jatropha curcas). Although palm requires less manual labour to harvest a given amount of oil than jatropha, the latter grows well in more marginal areas and requires less water.

Even though Oryza sativa is globally the most important cereal crop (together with - and depending on the years less or more important than - wheat, Triticum spp.), Africa has been the centre of origin of $\mathrm{O}$. glaberrima, the so-called upland rice that still has its main cropping area centred around the West African Niger river watershed. Dr. Monty Jones, formerly with the Africa Rice Centre, or West African Rice Development Association (WARDA) as previously known, was able to create a viable cross between both species, which is currently known as NEw RICe for Africa. NERICA blends the high(er) production potential of $\mathrm{O}$. sativa with the rusticity of 0 . glaberrima, and yields up to $30 \%$ more than the latter without the need for costly inputs such as fertilizer or pesticides (see www.warda.org for more background information). As such, NERICA can be a life saver for many resource-poor farmers, and should also allow them to secure additional income over their meagre subsistence earnings.

In terms of acreage, food, cultural, and commercial importance, these four product groups are the most important amongst the crops which have their origin in Africa. The rest of the list covers species that have only local and/or regional interest. If they or their by-products are exported, they serve specific 'niche' or seasonal markets with limited scope or impact.

\section{2. ....and some others}

Amongst the most important 'secondary' food crops of African origin, we can mention Pennisetum glaucum (pearl millet), Sorghum bicolor (sorghum) and Dioscorea spp. (yam). Where they occur, the three of them are important staples. Pearl millet is a basic food item whose flour is prepared into a sort of porridge that is the basis for meals in the semiarid areas of Africa. White-seeded sorghum serves the same purpose; the red-seeded variety, however, is the basis of sorghum beer. Its tannins guarantee a strong and specific 
taste that is appreciated both in the northern and southern hemispheres of Africa. The seeds of both species are also known on western markets where they are sold as birds' feed. Yams are another staple source of energy. Different species are still harvested from the wild, whereas others form an integral part of the farming system of the somewhat more (sub-) humid farming systems. As the vining Dioscorea needs a support, it is often grown in association with other crops, mainly cereals.

Vigna unguiculata (cowpea) is a legume that is typically grown in association with cereals. In West Africa, it especially occurs in mixed stands of millet and/or sorghum. Its centre of origin is situated in Nigeria. These three crops typically grow in semi-arid, low resource settings, and have low yields. Improved varieties do exist for all three, but yields are in the range of only i $t / h a$. Sorghum and millet are mandate crops for the International Crop Research Institute for the Semi-Arid Tropics (ICRISAT, headquarters in Hyderabad, India), whereas cowpea is a focal crop for the International Institute of Tropical Agriculture (IITA, Ibadan, Nigeria). Both institutes try to develop varieties with high rusticity and resistance against the more common pests and diseases.

The continent gave birth to a number of other cereals such as finger millet (Eleusine coracana) or fonio (Digitaria exilis), coracan (Eleusine coracana) or teff (Erahttp:/|www.ua.ac.be| main.aspx?c=.ICCRgrostis teff). The latter originated in Ethiopia, where it is a staple crop in part of the country - its flour is turned into enjeera which accompanies every 'proper' meal in Ethiopia. Teff is also grown in South Africa as cattle feed.

Apart from cowpea, there are still a few other legumes that have their centre of origin in Africa. Cajanus cajan is an important seed legume, whose grains are used for feed but also for human food. Pigeon pea is also a crop that is often used in improved agroforestry or agro-sylvopastoral systems in alley cropping configurations. It improves soil fertility and can also protect the field from degradation and erosion. Lablab (Lablab purpureus) is another legume that was initially domesticated in Africa.

Africa has also seen a number of vegetables developed from the wild. Solanum aethiopicum is a species that is rich in a number of subspecies, all of which are termed African eggplants (Van Damme, 1986). They have a somewhat bitter taste, and come in different forms and colours. Cucumbers (covered by a wide variety of Cucumis spp.) were also and initially developed from African material. Hibiscus sabdariffa (bissap or roselle) and $\mathrm{H}$. cannabinus (kenaf) are interesting Malvaceae. Red roselle is grown for its red succulent calices (that continue to develop once fruits are set) that once dried are the source of a sweet and sour beverage traditionally drunk by muslims during Ramadan. Kenaf is a source of coarse stem fibres. It is traditionally grown in garden plots; its fibres are made into ropes with specific uses. Lagenaria siceraria was amongst the first domesticated plants in the world. This cucurbit is basically grown for its calabash fruits that once dried are used as recipients. Ricinus communis (ricin) is also grown in garden environments, but its final uses are mostly medicinal. Guizotia abyssinica is the source of 'Niger seed'. It is an erect, stout, branched annual herb, grown for its edible oil and seed. Its cultivation originated in the Ethiopian highlands, and has spread to other parts of Ethiopia.

Apart from coffee and oil palm, trees or perennials are quite absent from this list. 
There are, however, a few African perennials that made it into 'real' crops such as Quercus suber, a north African tree species whose bark is a source of cork, that has many uses (see infra). Phoenix dactylifera, date palm, forms an essential part of the north African oasis production system. Dates are a very useful survival food. Rich in energy they are appreciated in numerous societies for their sweetness (Van Damme, 1998a). On the other hand, Cola nitida (cola nut) has a huge local, cultural and - more widely - traditional importance. Although it is traded widely across the region, it is of limited interest beyond its initial centre of domestication. At the same level, Ricinodendron heudelotii, Xylopia aethiopica or Tamarindus indica serve local and regional markets, but have barely a presence on the international market, unless we count the latter species for which there exists a ready market in Asia, and of late also Europe. With the exception of cork oak, there exist no improved varieties for the other species mentioned in this paragraph, 'real' domestication only having started recently.

Interest in the latter species has recently increased, partly because of the research and development work initiated by the World Agroforestry Centre (ICRAF). The latter is also true for Prunus africana, a species once coined a 'cinderella species' by Leakey and Jaenicke (1995) and Leakey and Newton (1994) to indicate this is a species with a multitude of hidden valuable uses that are (as yet) not appreciated by the wider (scientific/ development) community. P. africana is currently being domesticated as there is a huge market demand from the west for its medicinal bark. T. indica is part of the wider Domestication and Development of Baobab and Tamarind (DADOBAT) project that is currently being executed by the Laboratory of Tropical and Subtropical Agriculture and Ethnobotany, UGent (www.dadobat.soton.ac.uk; 2006-20I0).

\section{Under-utilised African Plant Species Waiting to be Domesticated}

From the above, it is clear that up till now Africa has been the source of only a few crops with 'universal' importance. Others remain confined to the continent. There are, however, a number of other useful species that are only known and used by local communities for food, medicine, rituals, dye, timber. Within this group, especially non-timber forest products (NTFPs) would seem to have at least some potential on a wider scale.

Ethnobotanical survey work documents plant use by local and traditional communities, and allows these species to be 'discovered' for wider use and further development. Ideally, ethnobotanical inventories form the basis for plant germplasm characterisation using classic morphological description through descriptors specifically developed for the species under scrutiny and more elaborate fingerprinting methodologies using AFLP, micro-satellites, and so on. Thus, the taxonomical position of the useful species can be clarified, and the existence of specific eco- and genotypes evidenced. The latter information is important if and when one wants to improve the existing material through crossings and breeding. Better knowledge of the existing germplasm would allow for the better material to be domesticated. In order to achieve this, species have to be propagated and the plants developed into 'real' crops for introduction as food or medicine for autoconsumption and/or commercial, 'niche' crop development. 
In a global economy, development of new commodities that address specific socalled niche markets seems imperative if one wants to guarantee ready market access to resource-poor farmers who often do not have the financial nor organisational means to start competing with established global-market products such as coffee, rubber, cacao or tea. The strong economic position of these latter crops has long been established. New 'players' will only be able to enter these markets if they can offer specific quality products, or else can start producing enormous amounts (that would lower or compensate fixed production costs). Both strategies, however, necessitate high investments which more often than not are not available.

Box I. The importance of niche commodities - Tonts \& Selwood, 2003

Diversification and niche marketing have become very important economic strategies for many rural small businesses, farmers and communities. As part of these strategies, new opportunities often emerge for traditional products and industries. In the case of Western Australia, this has contributed to the revitalisation of the sandalwood industry. While sandalwood has been exported from Western Australia for more than 150 years, for much of the second half of the twentieth century it was of little economic significance. In recent years, however, the industry has become increasingly entrepreneurial, successfully marketing its products into niche markets in the global economy. For farmers and communities in rural areas, the revitalisation of the sandalwood industry has also provided opportunities for economic diversification and a profitable way of tackling land degradation.

Biodiversity as a whole, and African plant biodiversity in particular 'has emerged in the past decade as a key area of concern for sustainable development. It provides a source of significant economic, aesthetic, health and cultural benefits. Although estimates vary, there is [a] general scientific consensus that the world is becoming less biologically diverse in terms of genes, species, and ecosystems. Rapid loss of biodiversity poses a global threat to human well-being'.

(cited from www.worldbank.org)

Ethnobotanical research in Africa has come up with some promising candidates for new crop development. In particular, a number of NTFPs (Non Timber Forest Products) have market potential as niche commodities. NTFPs specifically cover food (and feed) uses, are an alternative source of income or employment and can be a means for increasing land productivity through crop diversification. In what follows, we briefly present a few of them.

\subsection{NTFPs for Direct Use as Food and/or Feed}

\subsubsection{Seeds and Nuts}

Argania spinosa or the carob tree is from the Mediterranean area. In biblical terms it provided the food that ensured the survival of John the Baptist. In a more contemporary setting we can identify it as a source of argan oil, Ceratonia siliqua, which is commercially 
produced as an alternative sweetener and has been incorporated in chocolates and confectionery in general. By way of contrast, a number of Pistacia spp. either yield seeds or have been the source of 'mastic' for a very long time. Vitellaria paradoxa seed from the Sahel, is the source of shea (nut) butter which is used in food preparation but also in cosmetics: locally, women use it to treat their skin It is also exported to the West for more formal incorporation into cosmetics where it is used as a moisturizer and an emollient. Shea butter is also edible. It is used as a cooking oil in West Africa, as well as sometimes being used in the chocolate industry as a substitute for cocoa butter. As such, international markets have developed for the products mentioned above. The Novella Africa Initiative (http://www.allanblackia.info/) recently highlighted that for the first time, an edible oil from the seeds of the indigenous Allanblackia stuhlmannii will be extracted to produce commercial products to be sold throughout the world.

On a more local scale, the nuts of Tetracarpidium conophorum are cooked and traded as a snack on local markets in DRCongo. Panda oleosa nuts can be consumed directly or processed into a paste and used for flavouring vegetable dishes.

\subsubsection{Fruits}

Ziziphus mauritiana ('jujube') yields sweet fruits. Through research, new varieties have been developed that produce bigger fruits with better/sweeter flavours. The international market prospects of Balanites aegyptiaca, Parkia biglobosa (néré, or African locust bean), Uapaca kirkiana and Parinari macrophylla still need to be explored, while those of Sclerocarrya birrea, appear more promising as the plant is at a more advanced stage of development. However, locally and regionally commercial activities for most of these products/species are quite intense. Saba senegalensis yields very acid fruits that could appeal to specific tastes, and are locally already turned into juices (see examples from Senegal and Mali; own observations). The fruit pulp of Adansonia digitata or baobab is the source of a sweet juice that is already produced in Europe (France, Italy). The fruit contains seeds that are locally used in sauces, while the (dried) leaves, bark and seedlings are sources for a number of useful products (www.dadobat.soton.ac.uk). The fruits of different Aframomum spp. have a somewhat bitter/sour taste and are also known to have several medicinal properties. At present, the latter fruits only have local and regional importance in Central Africa.

\subsubsection{Vegetables}

West Africa has a number of local leaf vegetables amongst which Celosia argentia is quite important. The vegetable type celosia is the most important leaf vegetable of southern Nigeria and is popular in Benin, DRCongo, and Indonesia. It is grown in home gardens and small farms both for home consumption and marketing. The plants are vigorous annuals that grow rapidly from seed. They are upright with alternate leaves and few branches until near flowering time. The flowers are borne in dense heads that yield large numbers of edible seeds. The flowers are often brilliantly coloured, and the green foliage may contain large amounts of anthocyanin pigments. The leaves, young stems, 
and young flowers are eaten as a pot herb. Much of the pigment is lost on cooking, but the leaves retain a pleasant green colour.

Gnetum africanum (locally known as eru, koko, okok, afangi or fumbwa) and the very similar Gnetum buchholzianum (eru, koko) are amongst the most popular leafy vegetables of Nigeria, Cameroon, Gabon, DRCongo, Republic of Central Africa and Angola. They are locally and regionally widely traded and do have potential in western markets, especially to serve the diaspora which, in the USA, is ready to pay up to $50 \$$ for one kilogram of Gnetum africanum (Asaha, et al. 2000) (see infra). Gnetum africanum seeds have a high caloric value ( $438.83 \mathrm{kcal} / \mathrm{roog}$, or: fff $\mathrm{I}, 836 \mathrm{~kJ} / \mathrm{Ioo} \mathrm{g}$ ); the leaves are rich in proteins and minerals ( $\mathrm{Na}, \mathrm{K}, \mathrm{Ca}, \mathrm{Mg}, \mathrm{Fe}$ ) and contain all essential amino acids (Okafor, 1995). With technical assistance from ICRAF and local R\&D collaborators, farmers in the Centre Province of Cameroon and Bas-Congo (DRCongo) are currently propagating Gnetum africanum by cuttings for integrating in their cropping systems (Degrande, personal communication). To soften this rather tough vegetable, people often mix it with waterleaf (Talinum triangulare), another nutritious and easy-to-grow vegetable originating from Africa, with expanding commercial production (Grubben \& Denton, 2004).

The genus Solanum comprises at least roo African indigenous species. Besides the better known S. aethiopicum (cf. supra), some of the lesser known species can also be promoted as excellent leafy (and/or fruit) vegetables and they are major sources of income for many vegetable farmers and traders in urban and rural areas (Solanum anguivi, S. macrocarpon, S. scabrum, S. tarderemotum). They all have a somewhat bitter taste. S. tarderemotum has a high potential for becoming an economically important leafy vegetable for medium-elevation and highland regions in East Africa (Grubben \& Denton, 2004).

The young shoots of Megaphrynium macrostachyum (macaroni, angule, eheyi) are considered as a delicious vegetable in DRCongo. At the Kisangani market, it is often sold out early in the morning and consumers complain of the lack of supply. Little research has been carried out on this plant, but our own preliminary findings show its scope and potential for future development.

Bitterleaf (Vernonia amygdalina) is another important vegetable in West and Central Africa, which, once established, is easy to produce and rather resistant to drought, making it popular in home gardens. The laborious and time-consuming task of processing bitterleaf has encouraged the commercialization of its processed leaves. This processing is fast becoming a source of income in urban areas.

\subsubsection{Spices}

In the west pepper (obtained from Piper nigrum) is mainly used as a spice, but in Africa, the leaves and fruits of Piper guineense are also used for making tea or medicine. P. guineense has also insecticidal and fungicidal properties. There is a huge demand for P. guineense in Nigeria, where the species is rare. There exists an active regional market, but P. guineense is also exported to Europe from Equatorial Guinea, Ghana and Cameroon (Sunderland \& Obama, 1998). The British company Seasoning Pioneers uses P. guineense in its spice mix called 'West African seasoning'. Promotion of its cultivation has started in Cameroon and Nigeria. 


\subsubsection{Palms}

The Arecaceae family (formerly known as Palmae) has a prominent place where useful plants are concerned. Elaeis guineensis has already been mentioned as a source of vegetable oil (see 2.I.) and recently the latter oil has attracted some interest as a possible source of biofuel. However, using a food oil as a source of combustion would seem ill-advised in the light of the pressing issue of hunger that continues to dog many parts of the world, Africa in particular. Using limited soil resources for promoting yet 'another' cash crop should therefore not be promoted. Palm oil plants, however, can also be good sources of edible fruits, palm wine, and palm hearts. Borassus aethiopum yields a sweet sap rich in sugars, it is a source of palm wine whereas fruits are also eaten. Metroxylon spp. (sago palm, amylaceous pith inside the trunk) and Phoenix paludosa (palm hearts, but also the host of the edible and eaten palm worm) are other possible contenders.

\subsubsection{Mushrooms}

Even though mushrooms are not real plants, we consider them here as their main uses are often similar to those of plants. Worldwide, mushrooms are collected and used for food and medicine. A number of them can be cultivated, thus adding value to organic waste (growth medium) and creating additional incomes for local communities. Their sustainable collection can feed into production-marketing chains with international importance.

\subsubsection{Fodder}

The African continent also has some species that are valuable sources of fodder or browse: Acacia spp. and Atriplex spp. occur in dry and saline environments, resp. Prosopis spp. have been introduced from elsewhere; their sweet pods are rich in energy and can also be used as fodder.

\subsection{Alternative Sources of Employment/Income Generation}

Southern Africa has a number of bamboo species that can be used in construction, as a source of fiber for paper, etc. Rosin and turpentine/resins, and gums are produced by a number of broadleaved species, such as Sterculia setigera (gum for cooking) or figs (Ficus spp., idem) whereas Pinus spp. can also be rich sources of resins. bark). Tannins are collected from a number of Acacia spp. (with notably A. nilotica), Rhizophora and Avicennia spp. (which are mangrove species) and also Quercus spp. Tasar silk (sericulture) is produced by Antheraea spp. (butterfly) feeding on Terminalia tomentosa, T. arjuna, or Ziziphus mauritiana.

A special case is offered by Quercus suber, the cork tree, whose bark is used in a wide variety of applications. Cork's elasticity combined with its near-impermeability makes it suitable as a material for bottle stoppers, especially for wine bottles. Cork stoppers represent about $60 \%$ of all cork-based production. Cork's low density makes it a suitable material for fishing boats and buoys, as well as handles for fishing rods (as an alternative to neoprene). Cork is also used in the manufacture of musical instruments, particularly woodwind instruments, where it is used to fasten together different segments of the instrument and make the seams airtight. Sheets of cork, often the by-product of more lu- 
crative stopper production, are used to make floor tiles and bulletin boards. Granules of cork can also be mixed into concrete. The composites made by mixing cork granules and cement have low thermal conductivity, low density and good energy absorption characteristics (Karade, 2003).

\subsection{NTFPs as a Means for Increasing Land Productivity through Crop Diversification...}

Honey and beeswax are interesting by-products of beekeeping. As such, the latter activity is well-suited to developing countries, requiring little capital injection, and making virtually no demands on natural resources. Beekeeping may be carried out in conjunction with subsistence and modern agriculture (any scale of operation) and can be an integral part of an agricultural management system.

Acacia senegal apart from being a source of tannins, also provides gum arabic, fodder, fuelwood, poles, while its $\mathrm{N}$-fixing properties make it well-suited for integration in agroforestry systems. Vetiveria zizanioides (recently reclassified as Crysopogon zizanioides), although a native of India, is also well-known in Africa, and has some relatives in the genus. Several aspects of vetiver make it an excellent erosion control plant in warmer climates. Unlike most grasses, vetiver does not form a horizontal mat of roots; rather the roots grow almost exclusively downward down to 2-4 meters. This makes vetiver an excellent stabilizing hedge for stream banks, terraces and rice paddies. The close growing culms also help to block the runoff of surface water. Because vetiver propagates itself by small offsets instead of underground stolons, it is non invasive and can easily be controlled by cultivation of the soil at the boundary of the hedge. Vetiver is mainly cultivated for the fragrant essential oil distilled from its roots. Worldwide production is estimated at about 250 tons per annum. Due to its excellent fixative properties, vetiver is used widely in high end perfumes. It is contained in $36 \%$ of all western perfumes. Major producers of the oil include Haiti, Java, China, India, Brazil and Japan, indicating that Africa is still 'virgin'. The United States, Europe, India and Japan are the main consumers (Günther, I990).

\section{4. or Source of Niche Commodities}

Aloë spp. are among the newer, niche commodities (see infra) that have entered formal commercial markets. The genus is native to Africa and is common in South Africa's Cape Province and the mountains of (especially East) tropical Africa, and neighbouring areas such as Madagascar, the Arabian peninsula and the islands off Africa. Where they occur in Africa, they are collected and processed into cosmetics and skin products (see figure 3 for the specific case of Aloë developed from figure 2). Aloë species are also frequently cultivated as ornamental plants both in gardens and in pots. Many Aloë species are highly decorative and are valued by collectors of succulents. Some species, in particular Aloë vera, are purported to have medicinal properties. Other uses of aloës include their role in alternative medicine and in home first aid. Both the translucent inner pulp as well as the resinous yellow exudate from wounding the aloë plant is used externally to relieve skin discomforts and internally as a laxative. To date, research has shown that $A$. vera pro- 
duces positive medicinal benefits for healing damaged skin. Conversely, other research suggests A. vera can negatively affect healing (Vogler and Ernst, 1999). Some Aloë species have also been used for human consumption. For example, drinks made from or containing chunks of aloë pulp are popular in Asia as commercial beverages and as a tea additive; this is notably true in Korea. Aloë is used externally to treat a number of skin irritations. It has antiseptic and antibiotic properties which make it highly valuable in treating cuts and abrasions. It has also been commonly used to treat first and second degree burns, as well as sunburns and poison oak, poison ivy, poison sumac infections, and eczema. It can also be used as a hair styling gel and works especially well for curly or fuzzy hair. Aloë contains a number of medicinal substances that can be used as a purgative. The medicinal substance is produced from various species of aloë, such as A. vera, A. vulgaris, A. socotrina, A. chinensis, and A. perryi. Several kinds of aloës are commercially available: Barbadoes, Socotrine, Hepatic, Indian, and Cape aloës. Barbadoes and Socotrine are the varieties most commonly used for curative purposes. Aloë juices are the expressed juice of the leaves of the plant. When the leaves are cut, the juice that flows out is collected and evaporated. After the juice has been removed, the leaves are sometimes boiled to yield an inferior kind of aloes. The juice of the leaves of certain species, e.g. Aloë venenosa, is poisonous (parts of this paragraph have been inspired by www.wikipedia.com).

\section{From Under-Utilised Crop over Niche Product to Niche Market Development (see figure 2)}

Ethnobotany, and useful plant inventory work in general, can yield interesting information on which species could and should be developed into commodities for greater food safety and income generation. In a global market with increased competition for a limited number of 'universal' products, new players should try to focus on niche commodity production to facilitate expansion into new markets with new products for which prices can be fixed by producers.

According to Van Damme (1998b), niche crops (should) have the following profile:

I. be multi-purpose, combining a subsistence and/or cash finality, with erosion control and/or another function which makes them interesting to integrate in the (existing) cropping cycle and farming system;

2. have a local market (potential) so that dependency on regional and/or international markets and prices remains limited;

3. preferably combine food and non-food properties so that when the formal market collapses, producers can continue to use the commodity for autoconsumption;

4. be annual, or short-cycle, crops as this allows for a quick, i.e. on a seasonal basis, change of commodity produced when economic/environmental needs arise;

5. have high rusticity, i.e. be well-adapted to local circumstances and have enough plasticity to guarantee high yields in different and/or changing environments, whereas they are tolerant of/resistant to the most important pests and diseases which are known to be a problem; ideally, the latter property should be combined with 
6. limited need for modern/imported inputs; and

7. limited need for qualified/specialised labour; whereas still

8. guaranteeing high yields and (by extrapolation returns on investment through) rewarding market prices;

9. be easy to store without excessive losses nor input use; whereas it should

Io. be easy to dry/process harvests locally with limited level of costly technology; and also

II. easy to transport the commodity or its processed products at later periods over large distances at low cost;

12. bulking of produce is a further plus; whereas it should also be possible

13. to grow these crops intensively on small plots.

In other words, niche commodities respond to (new) needs and also create their own markets, directing the market dynamic and prices. As they do not compete with existing products, unit selling prices will be rather high especially in the beginning of their development. As discussed in Van Damme (1998b), in the recent past, Simmondsia chinensis (jojoba) and Aloë spp. have been developed into income-generating commodities for novel markets. Jojoba is the source of a wax that replaces sperm whale oil (for more info on Aloë, cf. supra). A number of the species presented sub 3. are good candidates for similar niche product development, if a number of crucial issues are addressed.

In what follows, we will present the case of Gnetum africanum, a locally important vegetable with more formal market development potential. Issues dealing with its current market(ing) chain and (future) niche potential will also be discussed. In a final more general section, we would like to highlight the role different stakeholders can play in (niche) commodity development.

\section{Gnetum Africanum (Eru, Fumbwa): Hype or New Vegetable? The Need for Domestication}

Gnetum africanum is found in Nigeria, Cameroon, Equatorial Guinea, Gabon, the Central African Republic, Congo-Brazzaville and DRCongo to Angola (Grubben \& Denton, 2004). The leaves of $G$. africanum are used as leafy vegetables (see supra), but its fruits and tubers can also be eaten as famine foods (Bahuchet, 1990; Van Damme, r998a). Containing all essential amino acids, fumbwa is an important source of plant proteins. The leaves are cut and shredded, and prepared as spinach or mixed into salads, stews and soups. The leaves are also used in the production of a local 'whisky' commonly exported to Nigeria (Mbah and Mih, 2001).

Fumbwa has a wide range of medicinal uses: the seeds and leaves are used as an antidote against serpent bites and arrow poisons; it is used to treat wounds, stomach ache, anthrax, fever and high blood pressure; as a dressing it is applied on warts and boils (Bouquet, I969; Burkill, 1994; Ndam, et al., 200I).

The liana is used in hunting and the transport of goods (Burkill, I994). In addition, the different dishes prepared with fumbwa have a huge socio-cultural value: it can be said that fumbwa determines the cultural identity of a number of local tribes in the central 
African region (Ndam et al., 2001).

Fumbwa is regionally widely traded. It can be gathered and sold the whole year round and is the most exploited and commercialized wild vegetable of Cameroon. Between I985 and 1994, export amounted to about 0.5 tons/year (Bokwe \& Ngatoum, I994), while in the late 1990 s figures for Cameroon had increased up to 3600 tons/year (Asaha, et al., 2000). There is an active market from Cameroon to Gabon, Central African Republic, Nigeria and Congo-Brazzaville. From there it goes to the diaspora in Europe and the USA. Table I shows the price evolutions in the market chain of fumbwa from a Cameroonian village to the diaspora in the USA.

\begin{tabular}{|l|r|r|}
\hline Region & CFA/kg & \$/kg \\
\hline Cameroonian villages & $25-150$ & $0.1-0.2$ \\
\hline Wholesale trade Yaounde & $125-250$ & $0.3-0.4$ \\
\hline Other towns & $250-700$ & $0.4-1.2$ \\
\hline Port of Idenau (Cameroon) & $500-1000$ & $0.8-1.7$ \\
\hline Nigeria & 4000 & 6.7 \\
\hline Great-Britain & 8000 & 13 \\
\hline USA & 30000 & 50 \\
\hline
\end{tabular}

Table 1: Variation of prices (in CFA/kg and equivalent $\$ / \mathrm{kg}$ ) of Gnetum spp. leaves at different levels (Asaha, et al., 2000)

Although not consumed by the inhabitants of Kisangani (DRCongo), 'fresh' fumbwa is exported in huge quantities to Kinshasa, where the wild stock of G. africanum plants has almost been completely destroyed. In 2006, 54 tons were exported to Kinshasa by the different air companies CAA, HBA and WBD (Bwama, et al., 2007). Figure I shows a simplified market chain for fumbwa from a village around Kisangani to the market in Kinshasa.

$\begin{array}{lllll}\text { Gatherers } & \text { Middleman } & \text { Wholesaler } & \text { Wholesaler } & \text { Retailer } \\ \text { in the village } & \begin{array}{l}\text { (transport from village } \\ \text { to airport or air company) }\end{array} & \begin{array}{l}\text { at Kisangani airport } \\ \text { or air company }\end{array} & \text { at Kinshasa airport } & \begin{array}{l}\text { at Kinshasa } \\ \text { market }\end{array}\end{array}$

Fig. 1: $\quad$ Simplified market chain for fumbwa from Kisangani to Kinshasa (adapted from Bwama, et al., 2007)

In the Kisangani markets, fumbwa is only sold in very small quantities to migrants from other parts of the DRCongo. Cutting, drying and packaging can help solve freshness problems, although most consumers still prefer 'fresh' fumbwa over dried produce. Fresh 'leathery' leaves can last for one week. There also appears to be a difference in taste of fumbwa originating from different regions. 
The mean income for a NTFPs gatherer in the DRCongo is $84 \$ /$ month. The mean income for a small dealer in fumbwa is $131 \$ /$ month. There are, however, some regional differences. A wholesaler operating between Bandundu and Kinshasa, earns 270\$/month whereas a wholesaler operating in between Equateur and Kinshasa earns 1352 /month, which is far above the salary of a teacher ( 50 to $70 \$ /$ month) or a medical doctor (I90 to 250\$/month) (Ndoye et al., 2007).

Most gatherers and small dealers in Cameroon are women. If men intervene in the market channel, they are mostly wholesalers (Kanmegne et al., 2007).

Trade in NTFPs (amongst which notably fumbwa) is one of the few income generating activities for women in marginalised rural regions. Fumbwa provides employment for women and children and thus an income for the most vulnerable groups.

Because of the large demand, fumbwa is becoming increasingly scarce in Nigeria and Cameroon, but also in Gabon, the Central African Republic and the Democratic Republic of Congo, over-exploitation of the fumbwa is already leading to a strong decline in this wild resource (Schippers, 2002). Gathering mostly occurs in a very destructive way, which does not allow regeneration of the plants (Shiembo, 1998). Domestication is thus urgently needed to preserve the genetic variation and to avoid species extinction. Domestication is taking place in Cameroon in the Mount Cameroon Project, Conservation through cultivation Program, at Limbe Botanical Gardens. This project constitutes a viable gene bank of Gnetum africanum and G. buchholzianum and is developing and disseminating effective cultivation techniques. Domestication trials are also going on at the INERA research station in Luki (DRCongo) and recently also in Kisangani (DRCongo).

Considerable quantities of fumbwa are lost due to poor marketing conditions: transport remains a major problem in these regions; market infrastructure is far below standard and market information is almost 'nihil' (villagers in Congo gather fumbwa and wait for middlemen to come or not). In addition to domestication trials, market studies and market chain analysis are urgently needed to provide a number of intervention strategies (e.g. grouping of gatherers, information systems,...) for improving the production, trade and commercialization of the so 'desired' fumbwa.

\section{Final Considerations: Who are the Major Stakeholders Who Should Promote African Botanical Heritage Development?}

According to a study carried out by Gabre-Madhin and Haggblade (200I) on successes in African agriculture, it has become clear that few (African) countries have accorded agriculture and new, plant-derived commodity development the necessary priority, either in policy debates or investment allocations, to sustain agricultural support institutions capable of generating a steady stream of innovation and growth. This persistent under-investment in frontline agricultural research and related support institutions appears puzzling at first. But after spending some time in African ministries of finance, it quickly becomes clear that narrow tax bases coupled with enormous debt loads and donor-imposed priorities on social spending leave little room for manoeuvre or debate over the relative role of productive investments in agriculture. An opening up of these budget 
debates will require a renewed commitment to agriculture and more specifically new crop development by both African governments and donors.

Governments wishing to intensify smallholder agriculture under circumstances where the necessary markets were/are absent or weakly developed should leave market activities to the private sector and try to foster market entry, investment and technological progress via interventions that promote institutional development (such as appropriate legislation, improved transport and social infrastructure, and administrative and legal services).

Public policy and developmental initiatives to encourage linkages between farmers and agribusiness include both direct and indirect support to smallholder market linkages and more general support to the smallholder sector. Direct support measures include the promotion of grassroots cooperation and facilitation by a specialised non-governmental organisation (NGO) increasing the business and technical skills of groups and developing good working relationships between groups and agribusiness.

Major donors have an important role to play to help farmers' organisations enter the policy dialogue with governments and other stakeholders so that an enabling environment (legal context for cooperatives and associations, taxes, regulations, and input quality control, level playing field for all suppliers) can be created. Donors could support farmers' organisations and governments establishing forums for policy dialogue between government, farmers' organisations (FO) and donors. It can also facilitate the linkages/interactions between producers and other stakeholders, such as input suppliers.

Donors should ensure that funding for FOs' capacity building, advisory services, communication, networking, etc. is available at decentralised levels and that decisions to allocate funding be in the hands of FOs. Funding should be available not only for services but also for improving local infrastructure in support of input supply and marketing, such as storage facilities.

Amongst the strong feelings that FOs are the key to future agricultural development were some warning voices against placing too much emphasis on FOs. These warnings came from different angles (Dirckx and Van Damme, 200I). In a field survey cum interviews organised by the latter authors, some companies expressed disillusionment with working with groups. They felt that it is wasting effort to do so and that it is forcing something onto rural areas that is not appropriate at this stage in their development. They believe that the focus should be more on individuals than on groups, the need is to strengthen the entrepreneurial base in rural areas. That will have more impact than trying to force groups into existence. Therefore, the establishment of associations should only be promoted if that is the way that people in that particular area want to go.

Gabre-Madhin \& Haggblade (200I) state that although some observers remain sceptical whether NGOs could replace government extension services, many respondents in their survey cite cases in which NGO projects provide extension support to understaffed and underfunded government extension services. Ultimately, the thorny issues of public salary levels, recurrent transport budgets and adequate staffing for government exten- 
sion services remain closely linked to the debate over the relative role of NGOs in African agriculture.

NGOs often mandate themselves to concentrate substantial resources on a small number of villages, often in difficult areas. This favours the development of innovative, empowering approaches, but at levels of unit cost beyond the reach of the public sector. Wide-scale reliability should be a key design criterion for any future approaches developed by NGOs or 'special projects'.

During our field survey, it was also found that there was a lack of information sharing between (international and local) (non-governmental) organisations implementing projects to enhance rural development, marketing strategies for small-scale farmers, organisation of farmers in groups, etc. In this context, the Forum for Agricultural Research in Africa (FARA; www.FARA-Africa.org) has an essential role to play in guiding international policy makers in developing enabling policies for agricultural and niche commodity development in Africa. The Sub-Sahara Africa Challenge Programme which is led by FARA offers a good opportunity to put theory into practice.

It could be of great value to look for mechanisms of information sharing between such organisations as much can be learnt from each others' experiences and the impact of certain activities could be improved.

\section{Conclusions}

To conclude, it can be said that donors and NGOs together with governments, have an important role to play in linking small-scale farmers to commercial sector activities, and to develop niche commodity value chains. By being a broker, NGOs can ensure that small-scale farmers' rights are protected in relations (e.g. in contract farming) with private agribusinesses that are in the early stages of privatisation. Contract farming often requires organisation of farmers in groups. Promotion of such groups should only be taken up if it is felt necessary by farmers themselves and in such a way that farmers feel confident with it. Through contract farming, farmers' organisations can grow and learn to undertake marketing activities by themselves. The final objective should always be to create independent farmers' organisations that are free to take their own marketing decisions, without being tied to an agribusiness company that has power to violate farmers' rights.

There are different crops or commodities which can be developed out of useful plant species that have shown potential to become the basis for niche products following ethnobotanical research, and which can become important cash crops for farmers. However, choices on which species to develop should be made only after domestication trials have proven successful and following careful market studies, as these will differ for each situation/species.

African biodiversity offers ample scope for niche commodity development, for greater food security, more sustainable livelihoods and local market development in a global environment. Research is per definition multi-disciplinary and involves multiple stakeholders. To obtain better results and adoption of domestication techniques and market 
strategies, research methodologies should be as participative as possible and combine indigenous and scientific knowledge in an integrated way. This approach clearly needs the 'right', i.e. enabling, policy environment.

THE ENABLING ENVIRONMENT

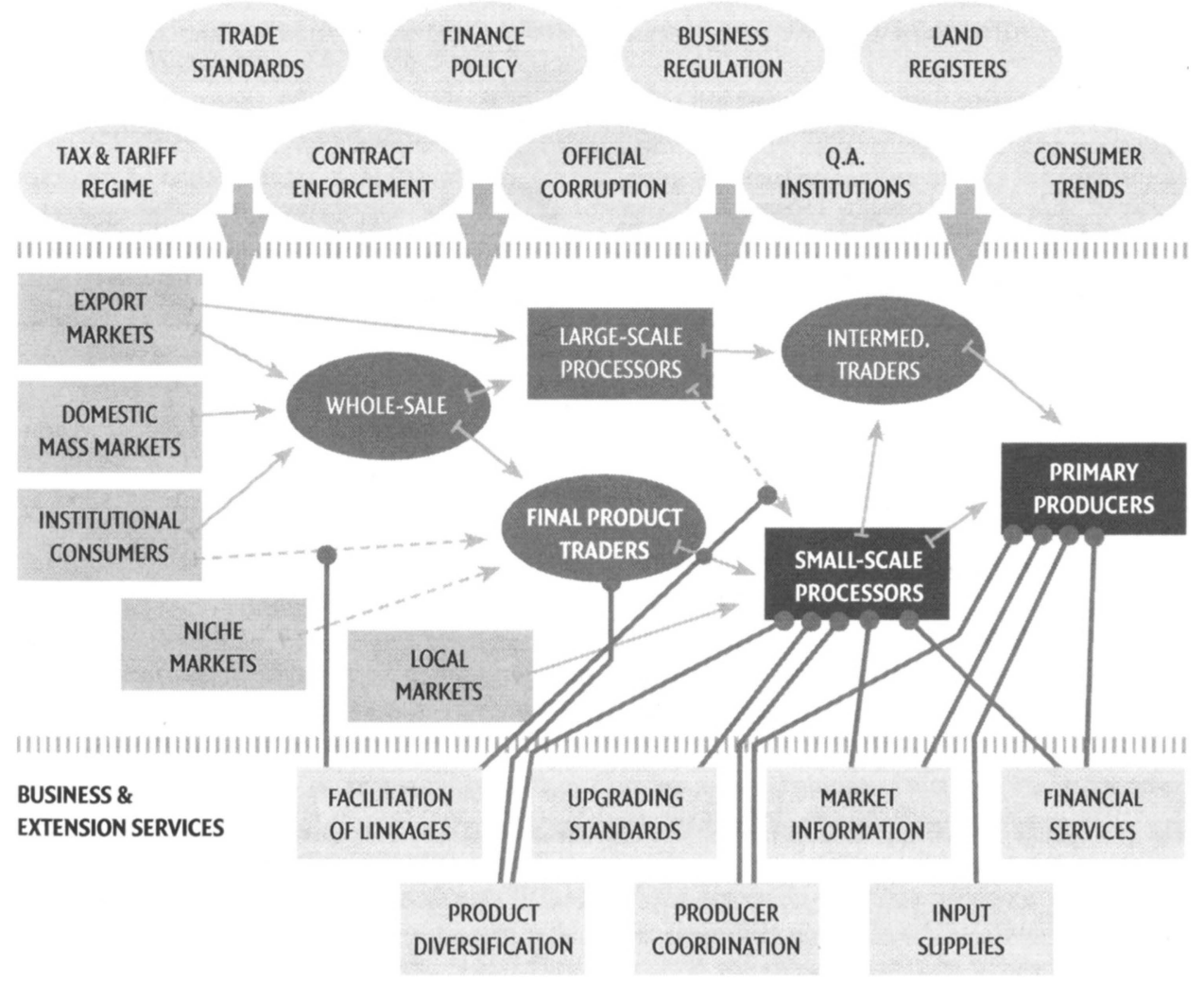

Fig 2: General 'generic' and schematic representation of any production - market chain and the (enabling) policy and socio-economic environment in which it operates, together with the business/extension services it needs in order to operate properly (from Hellin et al., 2005) 


\begin{tabular}{|c|c|c|}
\hline $\begin{array}{l}\text { CITES TRADE } \\
\text { RESTRICTIONS }\end{array}$ & $\begin{array}{c}\text { PRESIDENTIAL } \\
\text { DECREE }\end{array}$ & PREJUDICE \\
\hline
\end{tabular}

$\begin{array}{cccc}\text { FOREST } & \text { CORRUPTION } & \text { CONFLICT/ } & \text { LAND } \\ \text { ACT } & \text { IN LICENSING } & \text { INSECURITY } & \text { TENURE }\end{array}$

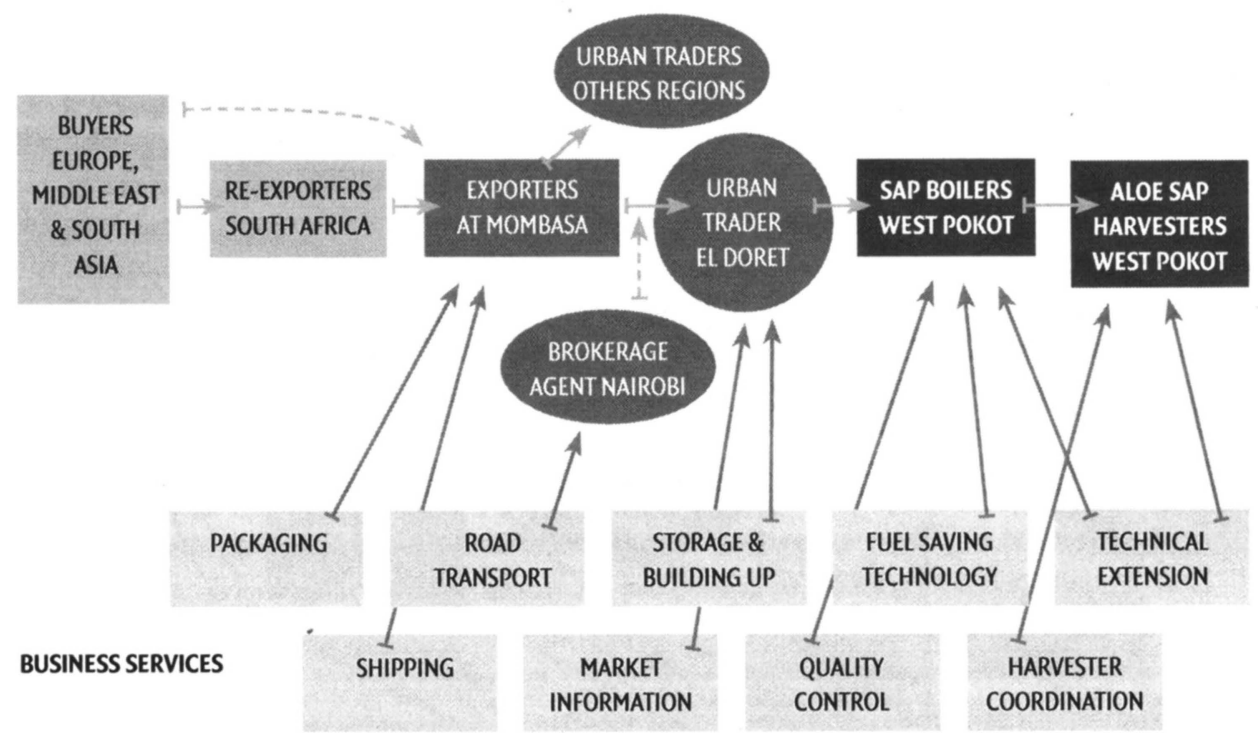

Fig. 3: Specific 'market map' developed from figure 1 (in collaboration with local stakeholders) and applied to Aloë spp. market chain with red arrows showing which activities in the market chain require specific services (from Hellin, et al., 2005)

\section{References}

ASAHA, S., TONYE, M.M., NDAM, N. \& BLACKMORE, P. (2000). "State of knowledge study on Gnetum africanum Welw. and Gnetum Buchholzianum engl." A report for the Central African Regional Program for the Environment. Cameroon, March 2000. Limbe Botanic Garden Library (II-15).

BAHUCHET, S. (1990). "The Akwa pygmies: Hunting and Gathering in the Lobaye Forest." In: Food and Nutrition in the African Rain Forest. Food Anthropology Unit 263, UNESCO."

BOKWE, A. \& NGATOUM, D. 1994. "Rapport de mission effectuée autour du Mont Cameroun (Province du SudOuest) relatif au recensement de certaines espèces des produits forestiers secondaires en voie de disparition." Rapport de la mission. MINEF, Yaounde.

BOUQUET, A. (1969). "Féticheurs et medicines traditionnelles du Congo (Brazzaville)." Paris, ORSTOM. Mémoires ORSTOM, 36, $282 \mathrm{pp}$.

BURKILL, H.M. (1994). “The Useful Plants of West Tropical Africa." Volume 2. Families E-I. Kew. Royal Botanic Gardens, Kew, 168-169. 
BWAMA, M.M., TERMOTE, C., DJAILO, D.B. \& VAN DAMME, P. (2007). "Etude préliminaire sur la contribution socio-économique de Gnetum africanum dans les ménages de la région de Kisangani." Annales de l'Institut Facultaire des Sciences Agronomiques de Yangambi. Vol. I, I17-132.

DIRCKX, T. \& VAN DAMME, P. (200I). "Linking small-scale farmers to commercial sector activities." The case of southern and eastern Sub-Sahara Africa. Beleidsvoorbereidend Onderzoek 200I. DGOS/VIIR/ UGent, $187 \mathrm{pp}$.

GABRE-MADHIN, E.Z. \& HAGGBLADE, S. (2001). "Successes in African Agriculture: Results of an Expert Study." Washington, International Food Policy Research Institute, $65 \mathrm{pp}$.

GRUBBEN, G.J.H. \& DENTON, O.A. (Ed.) (2004). "Plant Resources of Tropcial Africa 2." Vegetables. PROTA Foundation, Wageningen Netherlands / Backhuys Publishers, Leiden, The Netherlands/ CTA, Wageningen, The Netherlands, $668 \mathrm{pp}$.

GÜNTHER, E. (1990). "The Essential Oils." Vol. 4. New York, Van Nostrand, 178-18I; cited in Battaglia, S., The Complete Guide to Aromatherapy, Australia, The Perfect Potion, 1997.

HELLIN, J., GRIFFITH, A. \& ALBU, M. (2005). "Mapping the market: market-literacy for agricultural research and policy to tackle rural poverty in Africa." In: Almonds, F.R. \& Hainsworth, S.D. (eds.). Proceedings of the International Seminar: Beyond Agriculture: Making Markets Work for the Poor. London, UK, 28 Februay-I March.

KANMEGNE, J., OYONO BELINGA, J. M., DEGRANDE, A., TCHOUNDJEU, Z. \& TIKI MANGA, T. (2007). "Gender analysis in the commercialization of Gnetum africanum/buchholzianum in the Lekié division in Cameroon." Journal of Food Agriculture and Environment, 5 (I), 243-247.

KARADE, S.R. (2003). "An Investigation of Cork Cement Composites." PhD Thesis. BCUC. Brunel University, UK.

LEAKEY, R.R.B. \& JAENICKE, H. (1995). "The domestication of indigenous fruit trees: opportunities and challenges for agroforestry." p 15-26. In: Proceedings of $4^{\text {th }}$ International BIO-REFOR Workshop, Tampere, Finland, Suzuki, K., Sakurai, S., Ishii, K. \& Norisada, M. (eds.). BIO-REFOR, Tokyo.

LEAKEY, R.R.B. \& NEWTON, A.C. (1994). "Domestication of 'Cinderella' species as the start of a woodyplant revolution." p 3-5. In: Tropical trees: potential for domestication and the rebuilding of forest resources, Leakey, R.R.B. \& Newton, A.C. (eds.). HMSO, London.

MBAH \& MIH (200I). "Conservation through cultivation." An appraisal of the Mt. Cameroon Project Initiative on Eru. University of Buea.

MIALOUNDAMA, F. (1993). "Nutritional and socio-economic value of Gnetum leaves in Central African forest." In: Hladik, C.M. et al., Tropical forests, people and food: Biocultural interactions and applications to development. Parthenon, Carnforth (UK).

NDAM, N., NKEFOR, P. \& BLACKMORE, P. (200I). "Domestication of Gnetum africanum and G. buchholzianum (Gnetaceae), Over-Exploited Wild Forest Vegetables of the Central African Region." Systematics and Geography of Plants, 7I (2,) Plant Systematics and Phytogeography for the Understanding of African Biodiversity, $\mathrm{p} 739-745$.

NDOYE, O., AWONO, A. PREECE, L. \& TOIRAMBE, B. (2007). "Marchés des produits forestiers non ligneux dans les provinces de l'Équateur et de Bandundu: présentation d'une enquête de terrain." In: Croizer, C. \& Trefon, T. Quel avenir pour les forêts de la République Démocratique du Congo? Instruments et mécanismes innovents pour une gestion durable des forêts, $83 \mathrm{pp}$. (http://www.btcctb.org/doc/ UPL_2007080616534312165.pdf).

OKAFOR, J.C. (2005). "Conservation and use of traditional vegetables from woody forest species in south-eastern Nigeria." In: Proceedings of the IPGRI workshop on Genetic Resources of Traditional Vegetables in Africa, August 1995, Nairobi. Nairobi, IPGRI.

RUTHENBERG, H. (1976). "Farming Systems in the Tropics." Oxford University Press, U.K., 366 pp.

SCHIPPERS, R.R. (2002). "African indigenous vegetables." An overview of the Cultivated Species 2002 - Revised version on CD-rom. Natural Resources International Limited, Aylesford, UK, 244 pp. 
SHIEMBO, P. (1998). "The sustainability of Eru (Gnetum africanum and Gnetum buchholzianum): overexploited Non-wood Forest Product from the forest of Central Africa." In: Sunderland, T.C.H. \& Clark, L.E. (eds.). The Non-Wood Forest Products of Central Africa: Current Research Issues and Prospects for Conservation and Development. Food and Agricultural Organisation, Rome, 61-66.

SUNDERLAND, T.C.H. \& OBAMA, C. (1998). "A preliminary market survey of the non-wood forest products of Equatorial Guinea." International Expert Meeting on Non-Wood Forest Products in Central Africa, The Limbe Botanical Garden, Cameroon, I0-15 May 1998.

TONTS, M. \& SELWOOD, J. (2003). "Niche markets, regional diversification and the reinvention of Western Australia's sandalwood industry." Tijdschrift voor Economische en Sociale Geografie, 94 (5), 564-575.

VAN DAMME, P. (1986). "Comportement de deux aubergines africaines (Solanum aethiopicum et Solanum macrocarpon) dans la vallée du fleuve Sénégal." L'agronomie tropicale, 4I (3-4), 218-230.

_ (1998a). "Wild Plants as Food Security in Namibia and Senegal." The Arid Frontier. In: H.J. Bruins and H. Lithwick (eds.). The Arid Frontier: Interactive Management of Environment and Development. Kluwer Academic Publishers, Amsterdam (Chapter 12), 229-247.

_ (1998b). "Smallholder/Private Sector Policy and Programming Initiative for East and Southern Africa." Zambia Mission. Rome, IFAD, 46 pp.

VOGLER, B.K. \& ERNST, E. (1999). "Aloe vera: a systematic review of its clinical effectiveness." British Journal of General Practice, 49, 823-828.

WHITE, F. (1983). “The Vegetation of Africa," UNESCO, La Chaux-de-fonds, Switzerland.

\section{Internet sources}

www.fao.org, consulted during January 2008

www.warda.org, consulted January 2008

www.dadobat.soton.ac.uk - own website

www.worldbank.org, consulted September 2006

www.allanblackia.info, consulted December 2007

www.wikipedia.com, consulted December 2007 